\title{
Erratum to: Birt-Hogg-Dubé: beyond the clinical manifestations
}

\author{
Lindsay A. Middelton
}

Published online: 31 July 2013

(C) Springer Science+Business Media Dordrecht 2013

Erratum to: Familial Cancer (2013) 12:97-99

DOI 10.1007/s10689-012-9583-x

The article "Birt-Hogg-Dubé: beyond the clinical manifestations" is part of the Special Issue on Birt-Hogg-Dubé, unfortunately this article was inadvertently published in Volume 12, Issue 1, February 2013, pages 97-99.

The online version of the original article can be found under doi:10.1007/s10689-012-9583-x.

L. A. Middelton $(\square)$

National Institutes of Health, National Cancer Institute,

Urologic Oncology Branch, Bethesda, MD, USA

e-mail: middelt1@mail.nih.gov 